\title{
HUMAN-NATURE INTERACTIONS THROUGH THE LENS OF GLOBAL PANDEMICS: A REVIEW
}

\author{
${ }^{1}$ I. Budiman, ${ }^{2}$ R. K. Kusumaratna \\ ${ }^{1}$ Wageningen University, The Netherlands; '2Universitas Trisakti, Jakarta, Indonesia
}

The frequency of pandemics occurrence has increased, from every 200 years in period before the 18th century, to occurring every 10 to 50 years in the last century. The illegal and unsustainable wildlife trade, the devastation of forests and other wild places, and rapid human mobility were the driving forces behind the increasing number of diseases leaping from wildlife to humans. This article analyzes present human-nature interactions during COVID-19 and projecting future interactions after the pandemic, based on review on academic literature and reports from international development organizations. We found that global pandemic such as COVID-19 is altering humannature interactions in three major global ecological issues: wildlife, urban emission, and land use. For wildlife, COVID-19 affects human perception towards wildlife consumption and trade, as well as animal conservation. For land use, COVID-19 makes countries reduced efforts for forest monitoring and conservation. For urban emission, lockdown/mobility limitation and physical or social distancing policies are proven to some extent resulted in better human-nature interactions that reduce environmental problems. Reduced emission occurred from decreased industrial activities and mobilities. But this positive impact on environment may end once COVID-19 ends and human activities return to previous pattern. Therefore, structural change is required to prepare a resilient sustainable development by continuing existing positive human behavior during COVID-19 as a new normal of human-nature relationships. It is proven to reduce emission and if it is continued, it can have long term impacts on climate change mitigation.

Key words: human-nature interaction, COVID-19, emission reduction, resilience, adaptation

\section{ВЗАИМОДЕЙСТВИЕ ЧЕЛОВЕКА И ОКРУЖАЮЩЕЙ СРЕДЫ ЧЕРЕЗ ПРИЗМУ ГЛОБАЛЬНЫХ ПАНДЕМИЙ: ОБЗОР ЛИТЕРАТУРЫ}

\author{
() 2021 г. ${ }^{1}$ И. Будиман, ${ }^{2}$ P. К. Кусумаратна
}

\author{
${ }^{1}$ Вагенингенский Университет, г. Вагенинген, Нидерланды; ${ }^{2}$ Университет Трисакти, г. Джакарта, Индонезия
}

\begin{abstract}
Частота возникновения пандемий в мире возрастает. Так, если до XVIII века пандемии возникали раз в 200 лет, то в XX веке они объявляются уже каждые 10-50 лет. Нерациональное и незаконное природопользование, уничтожение природных ландшафтов и высокая мобильность населения являются основными движущими силами увеличения у людей числа заболеваний, до того встречавшихся только у животных. В данной статье представлен анализ взаимодействий человека и окружающей среды во время пандемии COVID-19 с прогнозом на пост-пандемийный период на основании обзора научной литературы и отчетов международных организаций. Результат качественного синтеза информации позволяет предположить, что пандемии меняют взаимодействие человека и природы в трех основных доменах: дикая природа, выбросы вредных веществ и землепользование. В первом домене в пандемию меняется потребление и торговля объектами дикой природы. В период ограничения мобильности и экономической активности людей значительно снижается эмиссия вредных веществ промышленными предприятиями и транспортом в окружающую среду, что благоприятно сказывается на взаимоотношениях в системе человек - природа. Однако положительный эффект на окружающую среду завершится с завершением пандемии и возвращением человечества к прежнему уровню экономической активности. Таким образом, опыт пандемий и связанные с ним изменения экономической и социальной активности человечества демонстрируют положительный эффект на окружающую среду и должны использоваться при планировании устойчивого развития в рамках новых взаимодействий человека и природы для уменьшения воздействий изменений климата на здоровье человека.
\end{abstract}

Ключевые слова: человек, окружающая среда, COVID-19, загрязнение, устойчивость, адаптация

\section{For citing:}

Budiman I., Kusumaratna R. K. Human-Nature Interactions Through the Lens of Global Pandemics: a Review. Ekologiya cheloveka (Human Ecology). 2021, 4, pp. 15-24.

Библиографическая ссылка:

Будиман И., Кусумаратна Р. К. Взаимодействие человека и окружающей среды через призму глобальных пандемий: обзор литературы // Экология человека. 2021. № 4. С. 15-24.

\section{Introduction}

There is a direct relationship between the histories of human-nature interactions and global pandemics. A pandemic is defined as "an epidemic occurring worldwide, or over a very wide area, crossing international boundaries and usually affecting a large number of people" [45]. While not a true pandemic because of its smaller scope, the first epidemic was recorded in Athens in 430 B.C.E. Until the $17^{\text {th }}$ century, pandemics and epidemics have occurred every 300 to 400 years. Some examples include malaria epidemics in ancient Rome, the first plague pandemic from 541 to 747 A.D. in the Mediterranean basin, the Japanese smallpox epidemic from 735 to 737 A.D., the second plague pandemic from 1346 to 1844 in mainland Europe, and the epidemics that spread throughout the Thirty Years' War from 1618 to 1648 in central Europe [37].

The frequency of pandemics has increased since the 
$18^{\text {th }}$ century, occurring every 10 to 50 years. Notable examples include the first global cholera pandemic in 1817, the 1918 Spanish flu, the 1957 Asian influenza [23], and the $2009 \mathrm{H} 1 \mathrm{~N} 1$ pandemic [22, 37, 43]. Due to the emergence of new virus subtypes as a result of virus re-assortment the increased frequency of pandemic occurrence has been attributed to the changing nature and intensification of human-nature interactions [72]. Those pandemics were triggered by negative humannature interactions. The illegal and unsustainable wildlife trade as well as the devastation of forests and other wild places were still the driving forces behind the increasing number of diseases leaping from wildlife to humans [21]. The changing of human-nature in land use has brought wildlife, livestock and humans in closer contact with each other and facilitating the spread of diseases, including new strains of bacteria and viruses [76].

COVID-19 is part of a pattern of increasingly frequent epidemics that have coincided with globalization, urbanization, and climate change. Interconnected nature of global risk accelerates the speed of transmission of the virus [73].

This article analyzes present human-nature interactions during COVID-19 and projecting future interactions after the pandemic, based on review on academic literature and reports from international development organizations.

\section{Research Methodology}

This study resulted from a review of scholarly literature (Figure 1). We used academic resources, peer review journal articles, and reports from international development organizations indexed in Google Scholar to identify relevant sources.

We utilized two search strategies. First, the key concepts are defined based on the research objective. We split the subject in the research questions into main themes. We identified three key concepts from the research questions; 1. Zoonotic disease, 2. Wildlife, and 3. Emission. These key concepts become the guideline for the search terms used in systematic literature review. By finding synonym or related topics for each concept, we formulate search terms per concept, for building a systematic query. These search terms are refined by doing some preliminary or simple searches.
Table 1

Search terms from key concepts

\begin{tabular}{|c|c|c|}
\hline 1 AND & 2 AND & 3 \\
\hline $\begin{array}{l}\text { Zoonotic diseases OR } \\
\text { Infectious diseases } \\
\text { Emerging infection } \\
\text { disease } \\
\text { COVID-19 } \\
\text { Pandemic } \\
\text { Lockdown }\end{array}$ & $\begin{array}{l}\text { Wildlife OR } \\
\text { Wildlife consumption } \\
\text { Wildlife poaching } \\
\text { Wildlife trade } \\
\text { Wildlife conservation } \\
\text { Wild animals }\end{array}$ & $\begin{array}{l}\text { Emission OR } \\
\text { Urban emission } \\
\text { Transport emission } \\
\text { Industrial emission } \\
\text { Air pollution } \\
\text { Urban pollution }\end{array}$ \\
\hline
\end{tabular}

We used three techniques in using the search terms. First is using combination of terms, with Boolean operators such as the words «AND», «OR» and «NOT», that are typed between the search terms. Second, we used wildcard technique, by adding the * or \# in places where an alternate spelling may contain an extra character. The database finds all citations of the word that appear with or without the extra character. For example, type fact* to retrieve results containing factor or factors. Third, for some terms such as technology dissemination, we used Proximity operator, to locate one word within a certain distance of another. The symbol used in this type of search are w/n(3). The w represents the word «with(in)» and the $n$ represents the word «near.» These techniques help to make each search more precise. Below is an example of query we used in conducting search in a database. Here are some examples of search strings conducted for this study:

- pandemic OR lockdown AND wildlife trade OR wildlife consumpt*

- urban W/3 emission OR air pollution AND pandemic OR COVID 19

For selecting articles to be reviewed from the search results, we used the following inclusion criteria:

- English language articles.

- Full text must be available.

- Peer-reviewed (for journal articles); included environment, public health and epidemiology papers.

- Further criterion is based on our subjective expertise on the subjects.

\section{Results and Discussion}

Earth is a complex matrix of living and inorganic systems, all interacting to maintain a stable balance.
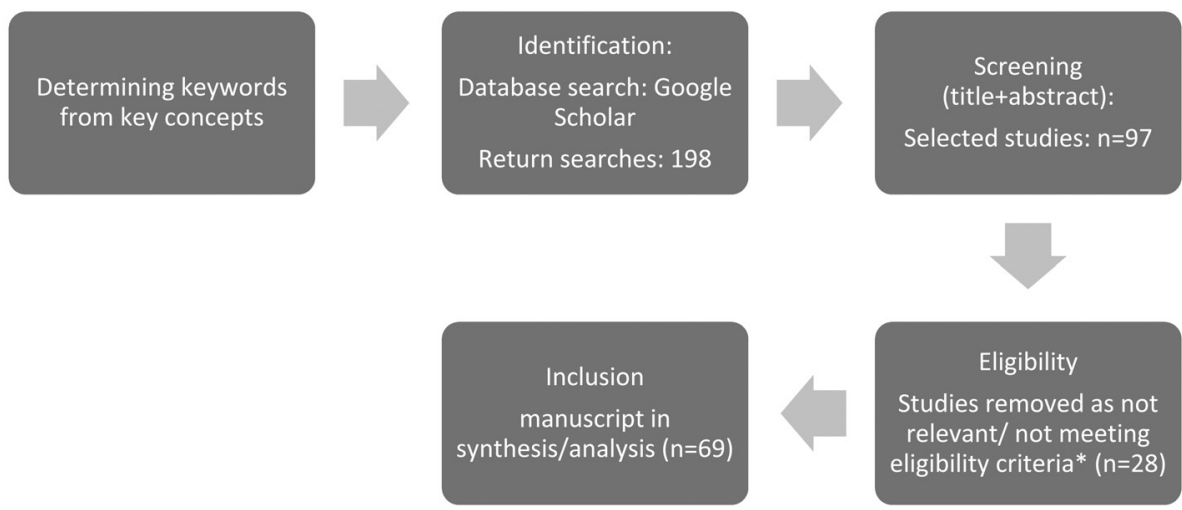
When one component of the larger matrix is damaged or destroyed, the others respond in their unique ways in attempting to restore the natural order of things [44]. Existing situation may reflect a human-nature interaction to restore the earth. Wildlife trading occurred along with devastating pressures on forest and natural ecosystems. It has led to the destruction of biodiversity that disturbed the stable balance of the earth. Human activities have significantly altered three-quarters of the land and two-thirds of the ocean, changing the planet to such an extent as to determine the birth of a new era of the "Anthropocene" [76].

As a result, COVID-19 may be a response to warn human to restore the earth. Global pandemic such as COVID-19 is altering human-nature interactions in three major global ecological issues: wildlife, urban emission, and land use. It is considered feedback mechanisms within earth system.

3.1. Human-wild animals' interactions: poaching, trade, and conservation

Human-wild animals' interaction through the lens of pandemic can be seen from three activities with complex direct and indirect pathways linking to both positive and negative outcomes for environment. First is wildlife poaching that is driven by a diversity of motivations such as consumption/culture, conflict, and economic reason [26, 42, 48]. In China, Vietnam, and Indonesia, wildlife consumption is a cultural practice [28]. Wild meat is the common product consumed and is used as a medium to communicate prestige and obtain social leverage, as well as to provide health benefits. As the countries' economy grows and its population ages, demand for wild meat products has increased [26, 67].

South East Asia suffers the world's highest rate of wildlife declines, due mainly to poaching [64]. Encroachment into wildlife habitat has driven the emergence of infectious diseases. Before COVID-19, there were Ross River virus disease in Papua, Indonesia and Nipah virus disease in Malaysia and Singapore. The encroachment may also have been a key factor also for the emergence of Plague in India and the USA.

Wildlife poaching is driven by economic benefit from wildlife trade. The unsustainable trade in Asia has been providing an income for some of the least economically affluent people and it generates considerable revenue nationally $[46,55]$. Wildlife trading is a human intervention that brings wildlife populations, domestic animals, and human living in proximity. International trade and the presence of introduced hosts had positive effects on the distribution of wildlife disease that is emerging at an unprecedented rate [25] posing major threats to human health and biodiversity.

Emerging infectious diseases (EID) events have risen significantly over time and dominated by zoonoses $(60.3 \%$ of EIDs): the majority of these $(71.8 \%)$ originate in wildlife [41]. There are two major groups of EIDs of free-living wild animals, on the basis of key epizootological criteria: (i) EIDs associated with zoo- notic "spill-over" (excretion and slaughter) from wildlife populations to domestic animals living in proximity; (ii) EIDs related directly to human intervention, via host or parasite translocations [58]. These phenomena have two major biological implications: first, many wildlife species are reservoirs of (high reproductive) pathogens that threaten domestic animal and human health; second, wildlife EIDs pose a substantial threat to the conservation of global biodiversity [25]. Biodiversity loss is disrupting natural balance of ecosystems. This shows how natural ecosystems and human health are closely connected.

Domesticated species, primates and bats were identified as having more zoonotic viruses than other species [40]. Globally, there are probably hundreds of undiscovered mammalian coronaviruses, many with the potential to infect human beings. Only three of the seven known human-infective coronaviruses cause severe disease. One of these, the Middle East respiratory syndrome coronavirus (MERS-CoV), has a high fatality rate and has spread internationally, including a 2015 South Korean outbreak that killed 38 people. MERS-CoV probably originates in bats [49] and spreads to human beings through dromedary camels [6].

COVID-19 outbreak was reported as a contaminated source from infected or sick wild animals in the wet market in Wuhan, China [78]. The virus was suspected to have passed through pangolins after originating in bats. Pangolins are endangered species that are poached and smuggled into China $[35,68]$. In the wet market, multiple wildlife species were butchered and sold, thus make this place had potential role as hotspots of crossspecies viral transmission [28]. Some such Asian markets have already been temporarily shut, reducing the legal and illegal trade in wildlife species, but zoonotic disease emergence from wildlife trade and consumption could arise on any continent [29]. Pathogens can transform quickly, which allows them to pass from wild animals to humans. These transmissions led to emerging diseases that endanger human lives and bring major socio-economic impacts [76].

Responding to the risk, conservationists are calling to stopping the wild animal trade for preventing pandemics. During the lockdown period, wildlife trade has reduced due to a decline in industrial activities such as manufacturing and the production of food. But, this decline has exacerbated local unemployment and economic insecurity, which may increase wildlife foraging in rural areas [10].

The rising tide of emerging diseases will force societies to reconsider their relationships with the environment, including wildlife conservation. Public health scholars argue that condemning wildlife exploitation and seek to replace it with fear and policing only handicap the real work of engendering respect for nature, weakening conservation in the long-term [28].

Depicting animals to the pandemic raise the negative perception to general people and hampers conservation [53]. Temporary declines in ecotourism to national parks 

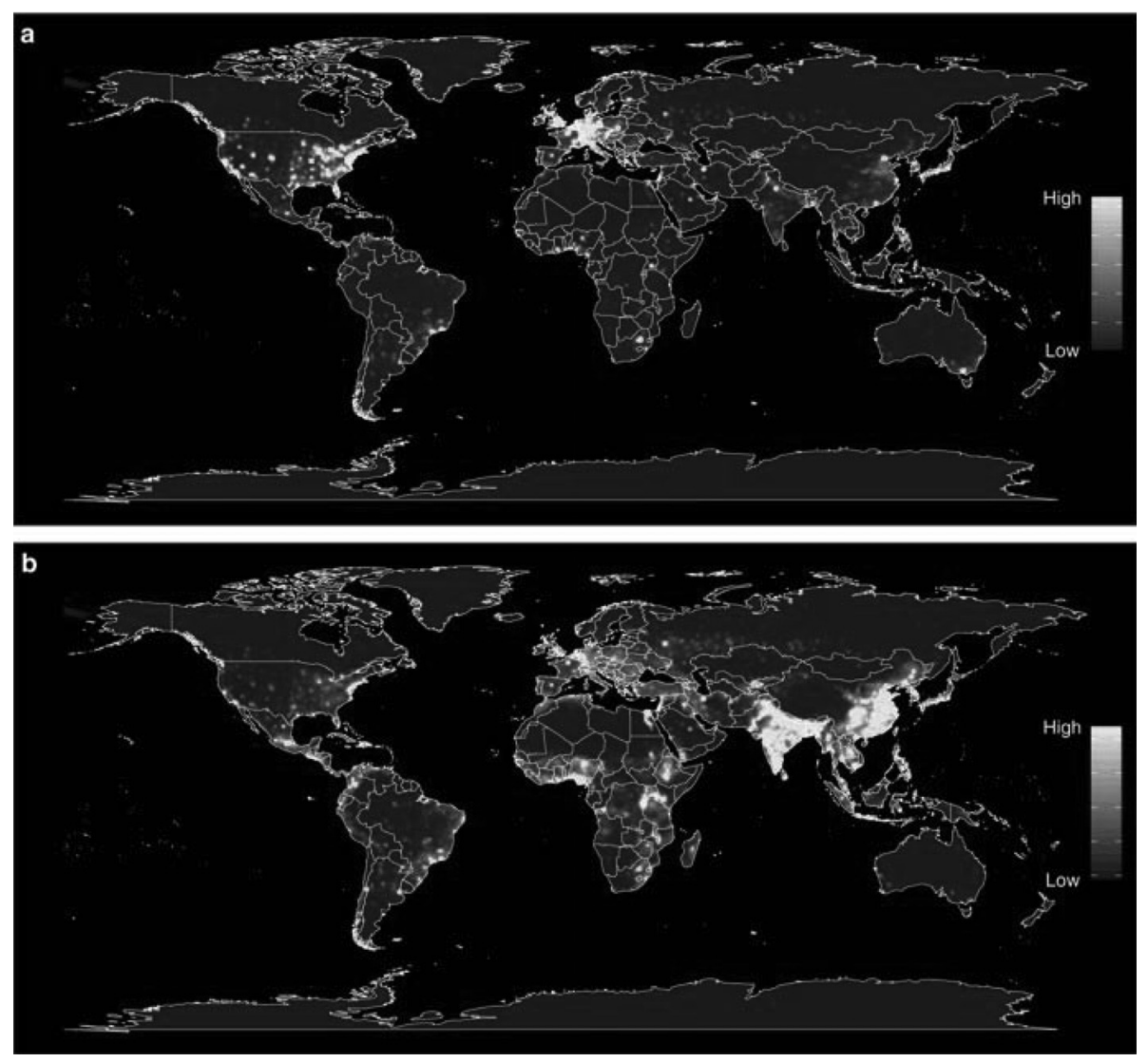

Figure 2. Zoonotic diseases risk is elevated in forested tropical regions experiencing land-use changes and where wildlife biodiversity (mammal species richness) is high (Allen et al., 2017)

and other protected areas may influence funding for anti-poaching and wildlife management programs [14, 54]. This makes natural habitat and fragile wildlife might receive less attention, resulting in potential big losses and a failure to reach conservation targets $[10,11,53]$.

Human-wildlife interactions are loosely related to deforestation, fires, and the emergence of infection disease in urban areas (Figure 1). Pressures of human encroachment on shrinking wildlife habitat cause increased wildlife population densities [1, 12]. Lack of urgent policy intervention to curb deforestation and fires, and to slow the quantities of animals entering the wildlife trade, are likely to increase the number of species loss for trade and bring infectious disease [29, 66]. The value chain of wildlife trade often ended in urban areas where human population expansion and density have increased the risk of zoonotic disease outbreaks and pandemic [16, 25].

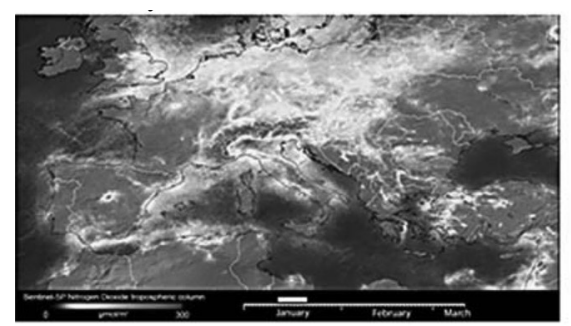

Before Lockdown

\subsection{Urban emissions}

In handling COVID-19, countries all over the world have been implementing different types of physical or social distancing policy, such as lockdown and social restriction. These policies are found to bring a positive impact to earth environment. Based on data released by NASA (U.S. National Aeronautics and Space Administration) and ESA (European Space Agency), human mobility is found reduced up to $90 \%$. This mostly came from air travel that is dropped by $96 \%$ and this is recorded as the lowest decrease in last 75 years. Figure 2 shows that the reduction influenced the decline of environmental pollution in atmosphere up to $30 \%$, in form of GHGs emission reduction that affects reduction of air pollution [51]. In China, Italy, Spain, and France, $\mathrm{CO}_{2}$ emissions is reduced up to $20-30 \%$ from the reductions in coal, gas generation, and transportation $[27,51]$. In northeastern part of USA, $\mathrm{NO}_{2}$ emissions

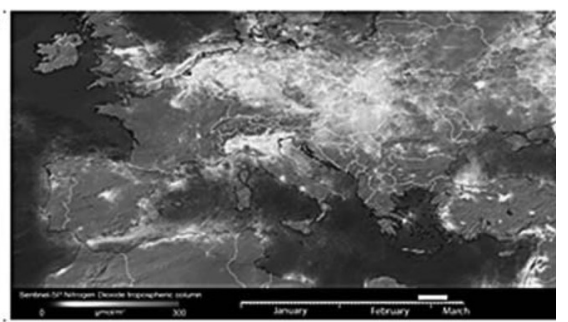

After Lockdown

Figure 3. Global Reduction in Human Mobility decreased NO2 emission by $30 \%$ 
is reduced up to $30 \%$ due to lockdown. In Java island, Indonesia, slight $\mathrm{NO}_{2}$ emissions reduction also occurred [34]. Major source of $\mathrm{NO}_{2}$ emissions reduction is the decrease on traffic pollution. The limited mobility looks like a new version of silent spring where the northern hemisphere is relatively silent from human activities.

Physical or social distancing policies do not only limit the transmission of COVID-19, but also reducing dangerous GHG emission that increases mortality rate of COVID-19. $\mathrm{NO}_{2}$ is considered highly lethal to human health as studies shows that both short term and long term exposure to $\mathrm{NO}_{2}$ can increase mortality rate [31]. $\mathrm{NO}_{2}$ may cause bronchial hyper responsiveness, cellular inflammation and respiratory problems. This point relates to pneumonia as respiratory problem that often found in patients infected with COVID-19 [7]. Severe acute respiratory syndrome coronavirus 2 (SARS-CoV-2) infects host cells through angiotensin converting enzyme 2 (ACE2) receptors, leading to coronavirus disease (COVID-19)related pneumonia, while also causing acute myocardial injury and chronic damage to the cardiovascular system [80]. $\mathrm{NO}_{2}$ emission reduction contributes to decline risk of human exposure to pneumonia and its acute injury and chronic damage from COVID- 19.

The next question is does emission reduction help to avoid severe air pollution? Study in China found that large emissions reduction in transportation and slight reduction in industrial would not help avoid severe air pollution, especially when meteorology is unfavorable. In cities like Beijing, Tianjin, and Shijiazhuang, emission reduction is lower than pollutant formation due to unfavorable meteorology. There was seldom wet deposition of PM (particulate matter) in Beijing due to the rare of rains during the lockdown period. The low PBL (planetary boundary layer) increased atmospheric stability, the low wind speed made it worse for difficult dispersion of air pollutants. High RH (relative humidity) and temperature usually accelerate secondary PM formation by speeding up chemical reactions. In Wuhan and Jinan, favorable meteorology helped emissions reduction in transportation and industries to avoid severe air pollution [69].

Slight emissions reduction would also not help to avoid severe air pollution in dense areas with lack of green spaces. Lack of green spaces means no trees to absorb emission; fewer trees and plants to clean the air and provide oxygen. It suggests that lack of green spaces reduce common health conditions of people live in dense areas [75].

In India, a study in 22 cities found that there is substantial reduction in concentrations resulted in a 4 times reduction in total emission reduction. PM 2.5 is found having maximum reduction in most of the cities. Like in China, PM2.5 could increase due to unfavorable meteorology, but the average concentration would still be under the national ambient air quality standards in India [63].

In Jakarta, Indonesia, PM 2.5 decreased from $44,55 \mu \mathrm{g} / \mathrm{m}^{3}$ to $18,46 \mu \mathrm{g} / \mathrm{m}^{3}$ in two weeks after social restriction policy. This figure is recorded as the best air quality in the city for the last 28 years [30]. The same pattern is also found in other four cities in the country [59]. These findings from China, India, and Indonesia shows that emission reduction helped to reduce average air pollution to some extent.

Global Carbon Project from Stanford University predicted that COVID-19 could result in a $5 \%$ fall in global carbon emissions, or around $2.5 \mathrm{bn}$ tones, by the end of 2020 [3]. This suggests that COVID-19 as earth's response has forced human to reduce their emission and pollution. When many environmental targets and commitments such as sustainable development goals including climate action has fallen short in the last decades, COVID-19 may be an extreme nature-based solution for tackling socio-environmental challenges.

Nevertheless, the fall in emission could be short-lived and have little impact on climate change mitigation [52]. It is because COVID-19 may not be last long as countries are currently racing to create the vaccines, to save human civilization and world economy. Once COVID-19 ends, the emissions could rise back to previous normal as business as usual. This emission recovery after COVID-19 is already seen in China. A study found that most provinces in East China gradually regained some of their $\mathrm{NOx}$ emissions after lockdown ended in February 2020 [79].

\subsection{Land use}

In addition to emission, COVID-19 has also impacted environment through reduced industrial activities. The manufacturing sector is found is the most impacted sector. COVID-19 has impacted their operations, productivity, and supply chain [60].

Some people argue that panic buying due to $\mathrm{CO}$ VID-19 may increase industrial production. In fact, the most popular items since the start of the outbreak have been dry goods, frozen foods, comfort snacks, power beverages and water [24]. It is dominated by fast moving consumer good industry. This industry has difficulty to currently increase their production as the factories are currently having issues with their workforce and productivity. This situation could have knock-on effects for the entire global supply chain of their products.

Those situations show that the reduction of industrial activity does not only reduce emission but also potentially reduce the use of natural resources and generate less waste [38]. As a result, it brings lower environmental impact to biosphere: the surface, atmosphere, and hydrosphere of the earth.

Meanwhile, trading behavior is currently shifting significantly to online shopping. Due to sharp increase on households' spending particularly in retail, credit card spending and food items [8], conventional supermarkets are thinking about ways to get more traffic on their websites as number of people want to stay home is growing [24]. This contributes to reduce carbon footprint for shopping activities. 
Besides abovementioned positive impacts to environment, countries' responses to COVID-19 could also bring negative impact to environmental conservation. In Brazil, indigenous groups - the forest's main defenders - are infected by COVID-19 and retreating into isolation to avoid the disease and appealing for food and medical supplies. This situation reduces forest monitoring efforts by the indigenous groups. While other stakeholders' attention may also decline. Multiple stakeholders are currently focusing on handling COVID-19 as health and economic crisis [5]. Government focus on the crisis causes fewer law enforcement officials are going out into the field and some monitoring missions are being scaled back $[4,70]$. This reduces attention to environmental protection and opening the door for land invasion and forest clearance triggered by economic crisis due to COVID-19 [65].

Same threat is happening to other forest and peatland countries, particularly rainforest regions in developing world such as Indonesia. These areas have indigenous groups who live in harmony with forest and supporting peatland restoration [17]. Slow handling of the COVID-19 in some developing countries brings the risk of COVID-19 infection to indigenous people. This could weaken rainforest and peatland protection.

Another negative impact to environment is the widespread practice of spraying disinfectant and alcohol in the sky, on roads, vehicles, personnel, and housings. Some speculative studies about COVID-19's spread by the airborne route made the government in some countries conducted air disinfection of cities and communities. This measure is not known to be effective for disease control. The widespread practice of spraying disinfectant and alcohol are potentially harmful to humans, biodiversity, and water bodies [77]. This negative impact is rather caused by lack of policymakers' knowledge about interaction or impact of the widespread practice of spraying disinfectant to environment.

4. Discussion and Conclusions: Preparing a resilient sustainable development

Table 1 shows several human-nature interactions that contributed to the emergence of pandemic and a number of changing in human-nature interactions resulted from pandemic related policies.

Physical or social distancing policies created by human is proven to reduce environmental problems, but this positive impact on environment may end once COVID- 19 ends and human activities return to previous pattern. Therefore, structural change is required to prepare a resilient sustainable development by continuing existing human behavior during COVID-19 as a new normal of human-nature relationships. It is proven to reduce emission and if it is continued, it can have long term impacts on climate change mitigation and the stable balance of the earth.

Infectious diseases such as COVID-19 were named one of the top 10 risks in terms of impact for the next 10 years [72]. South and East Asia is predicted as
Table 2

Human-nature interactions in different sectors that are linked to pandemics and its responses

\begin{tabular}{l|l|l|l}
\hline \multicolumn{1}{c|}{$\begin{array}{c}\text { Type of } \\
\text { interactions }\end{array}$} & \multicolumn{1}{c|}{ Wildlife } & \multicolumn{1}{c}{ Urban activities } & \multicolumn{1}{c}{ Land use } \\
\hline $\begin{array}{l}\text { Contribute } \\
\text { to the } \\
\text { emergence of } \\
\text { pandemics }\end{array}$ & $\begin{array}{l}\text { Poaching, } \\
\text { Food } \\
\text { consumption, } \\
\text { (Illegal) trade }\end{array}$ & $\begin{array}{l}\text { Intensive mobility, } \\
\text { crowding in public } \\
\text { transports, lack of } \\
\text { healthy behavior }\end{array}$ & $\begin{array}{l}\text { Deforestation, } \\
\text { reduced } \\
\text { biodiversity rate }\end{array}$ \\
$\begin{array}{l}\text { Impact of } \\
\text { pandemic } \\
\text { policy } \\
\text { measures }\end{array}$ & Animal & $\begin{array}{l}\text { Reduced emission } \\
\text { fonservation decreased } \\
\text { industrial activities } \\
\text { and mobilities }\end{array}$ & $\begin{array}{l}\text { Reduced efforts } \\
\text { for forest } \\
\text { monitoring and } \\
\text { conservation }\end{array}$ \\
\hline
\end{tabular}

hotspots for future zoonotic diseases because of its high human population density, high biodiversity, and rapid environmental changes [2]. Thus, mitigation and adaptation strategies are proposed to prepare a resilient sustainable development toward future risk. Further work is required to detailing these strategies and adapt it with various national/local context.

4.1. Preventing negative human-nature interactions Mitigation is considered actions that prevent negative human-nature interactions that can lead into global risks such as pandemics. To mitigate the increase of pandemic frequency, several things need to be done. First, all stakeholders worldwide must act to strictly regulate the wildlife related activities that brought a novel virus to human life. It is time to end the exploitation of wildlife and wildlife habitats that increases human exposure to pathogens that jump from animals to humans [36]. Banning trade may lose our ability to regulate it, to protect endangered species and securing way of animal consumption. Scale of the wildlife related practices such as hunting, trade, food consumption must be strictly regulated and enforced. For example, community outreach is needed for telling risk of unhygienic poaching and high volume of wild animals consumption [64]. Decision-makers must adopt a holistic approach to inform national and local policy responses to pandemic risks posed by wildlife trade [13].

Scientists, practitioners and policymakers must also address the challenges arising from the radically altered economics, attitudes and behaviors imposed by Covid 19 to animal conservation [29]. Better risk management is required on wildlife conservation activities, such as socialization, and implementation of one health concept as a multidisciplinary and collaborative approach to prevent the emergence of new zoonosis. The one health concept acknowledges the link between human health to animal and environmental health.

Although some wildlife related activities such as wildlife consumption is a "fundamental cultural and economic practice", the global threat from coronaviruses is too great. Scholars argue that even with extensive wildlife trade bans, crippling zoonotic disease burden remains a near certainty in the absence of strengthened health systems [28].

Second, an effort for predicting pandemics is required [50]. There is a growing need for globally predictive 
models of the future distribution of species that incorporate both climate and human movement patterns. By integrating factors associated with both fundamental niche predictors and propagule pressure predictors, monitoring and management of species conservation can be done for guiding the development of global models for species invasions and pathogen emergences [47].

Since 2009, more than 60 countries have been working together to build capacity and strengthen zoonotic pathogen surveillance and identified at least 931 novel virus species from 145000 samples of wildlife, livestock, and humans. viral discovery is not enough to prevent pandemics [20].

Third, regulation and its enforcement on food safety need to be improved. Zoonotic diseases like Covid-19 thus reveal distressing dimensions of the global agriculture and food system that are not adequately understood or regulated through private commerce [35]. It brings the risk of foodborne disease. Thus, it is mandatory for producers to adopt, apply and implement Hazard Analysis and Critical Control Points (HACCP) system, an application to ensure food safety process with general principles of food hygiene by the Codex [74]. Besides, it is essential for the food industry to strengthen personal hygiene measures to avoid or minimize the risk of viral contamination. Furthermore, high risk foods e.g. raw milk, fresh meat, fruit or vegetables handled by a person with the virus or drinking water contaminated with feces or urine might also possible to transmit the virus [32]. Fourth, we also must stop deforestation to maintain healthy ecosystems for wild animals. In addition, reforestation also contributes to increase ability of forest vegetation to absorb emission and to reduce pollution. This relates to adaptation strategy to support cleaner air for better health.

4.2. Building positive feedback mechanisms from human to natural environment

Adaptation does not only mean to adapt with future risks, but also to build more positive feedback mechanism from human to earth environment. Lessons learned for adaptation strategies can be derived from Korea's experiences from post-2008 crisis and current China recovery from COVID-19. After financial crisis of 2008, China and South Korea are two countries that put highest stimulus to green measures, compared to other countries. Green stimulus is defined here as short-run fiscal stimuli that also serve a "green" or environmental purpose in a situation of "crisis" characterized by temporary under-employment [9]. South Korea allocated $80 \%$, and China put almost $40 \%$ of their 2009 stimulus to green growth in energy efficiency, renewable energy, low carbon industries, material consumption sectors (Robins et al., 2009). As a result, South Korea rebounded their GDP growth faster than the rest of OECD countries [57]. This growth is proven green as the increase rate of carbon emission in South Korea and China declined, while global carbon emission continued to rise in the same rate [33].
To recover from COVID-19, China is currently upgrading their green measures with adding resilience factor into consideration. The new investments start to focus on building resilience to future risks [75]. Attention is put to some 'light-touch' sectors such as information services (big data), medical, education (online learning), entertainment, logistics (resilient supply chain), and industrial robot. By April 2020, online working is found to increase by $537 \%$ and online education is also increased by $169 \%$ [71]. In addition, China also build new infrastructures such as $5 \mathrm{G}$ internet network, ultra-high voltage, inter-city transportation, and new energy vehicle battery as well as its charging stations. In cities, the country accelerates promotion of new schemes such as waste to energy, new safe mobility and energy storage infrastructure [75]. With this vision, China economic recovery index reached $86 \%$ by the end of March 2020, about two months after lockdown.

Other countries can learn from China and Korea about strategy of recovery from health and economic crisis, and to adapt with future risks by starting a new normal. Other sectors that can also be upgraded are finance, trade and investment, and food-energy-water nexus. Industries must apply fair trade principles along their value chain, to support vulnerable groups. Water, food, and energy sectors must consider decentralized system to anticipate the risk of supply chain disruptions in the future. These transformations require a resilient governance model with high degree of distribution of power and cooperation [18].

Financial acts such as Bank can put sustainability and resilience into consideration in providing investment and loan for businesses [19]. This includes investment in resilient infrastructure for core services and housing for dense areas in cities as the most vulnerable areas to pandemics. Urban regeneration can be considered for housing in vulnerable districts to anticipate readiness for physical/social distancing in the future. One of important core services is public transportation. Public transit systems require new measures such as heightening routine cleaning protocols, separating drivers from passengers with temporary barricades, and using floor markings to indicate safe distances between riders. Besides, cities must create alternatives to public transit by promoting walking and cycling as healthier and environmental-friendly lifestyle [56].

For cities, post-COVID-19 period is an enormous opportunity to respond and recover more inclusively and with greater resilience. Besides green and resilient economic development, cities must also provide strong social and fiscal safety nets for informal \& low-wage workers. This must be followed with targeted financial support for vulnerable communities [62, 75]. In addition, national-local coordination and arrangement for disaster response and recovery must be improved with the use of data in city and neighborhood level to monitor risks.

In community level, behavior change is a key. More collective actions are required to support sustainability and resilience in neighborhoods [15, 39]. For example, 
local food security can be advanced through urban farming, to adapt with the future risk of food crisis due to pandemics. Daily activities such as working and studying must start to shift to online mode by encouraging online meetings/events. This will decline economic and environmental cost of the activities by reducing travel cost, its emissions and pollution.

\section{Acknowledgements}

Thanks to WRI Indonesia, PPI Amsterdam, and Trisakti Disaster Management Center (TDMC).

Ibnu Budiman - ORCID 0000-0002-9128-0866

Rina Kusumaratna - ORCID 0000-0002-9905-3406

\section{References}

1. Alexander K. A., Kat P. W., Munson L. A., Kalake A., \& Appel M. J. Canine distemper-related mortality among wild dogs (Lycaon pictus) in Chobe National Park, Botswana. Journal of Zoo and Wildlife Medicine. 1996, 27 (3), pp. 426-427.

2. Allen T., Murray K. A., Zambrana-Torrelio C., Morse S. S., Rondinini C., Di Marco M., Breit N., Olival K. J., \& Daszak, P. Global hotspots and correlates of emerging zoonotic diseases. Nature Communications. 2017, 8 (1), pp. 1-10.

3. Ambrose J. Carbon emissions from fossil fuels could fall by $2.5 \mathrm{bn}$ tonnes in 2020. Environment. The Guardian. 2020. Available from: https://www.theguardian.com/environment/2020/apr/12/global-carbon-emisions-could-fall-byrecord-25bn-tonnes-in-2020 (accessed: 15.09.2020)

4. Aqil I. Covid-19, a new challenge in forest fire control. The Jakarta Post, 2020. Available from: https://www.thejakartapost.com/news/2020/05/28/covid-19-a-new-challengeforest-fire-control.html (accessed: 15.09.2020)

5. Arumingtyas L. Tantangan Pengendalian Karhutla pada Masa Pandemi. Mongabay Environmental News. 2020, June 11. Available from: https://www.mongabay.co.id/2020/06/11/ tantangan-pengendalian-karhutla-pada-masa-pandemi/ (accessed: 15.09.2020)

6. Azhar E. I., El-Kafrawy S. A., Farraj S. A., Hassan A. M., Al-Saeed M. S., Hashem A. M., \& Madani T. A. Evidence for camel-to-human transmission of MERS coronavirus. New England Journal of Medicine. 2014, 370 (26), pp. 2499-2505.

7. Bai H. X., Hsieh B., Xiong Z., Halsey K., Choi J. W., Tran T. M. L., Pan I., Shi L.-B., Wang D.-C., \& Mei J. Performance of radiologists in differentiating COVID-19 from viral pneumonia on chest CT. Radiology. 2020, p. 200823.

8. Baker S. R., Farrokhnia R. A., Meyer S., Pagel M., \& Yannelis C. How does household spending respond to an epidemic? Consumption during the 2020 COVID-19 pandemic. National Bureau of Economic Research. 2020.

9. Barbier E. B. Green stimulus, green recovery and global imbalances. World Economics. 2010, 11 (2), pp. 149-177.

10. Bates A. E., Primack R. B., Moraga P., \& Duarte C. M. COVID-19 pandemic and associated lockdown as a "Global Human Confinement Experiment" to investigate biodiversity conservation. Biological Conservation. 2020, 248, p. 108665. https://doi.org/10.1016/j.biocon.2020.108665

11. BI B. The conservation disruption: When Covid struck. BirdLife, 2020. Available from: https://www.birdlife. org/europe-and-central-asia/news/conservation-disruptionwhen-covid-struck (accessed: 15.09.2020)
12. Bloomfield L. S., McIntosh T. L., \& Lambin E. F. Habitat fragmentation, livelihood behaviors, and contact between people and nonhuman primates in Africa. Landscape Ecology. 2020, 35 (4), pp. 985-1000.

13. Booth H., Arias M., Brittain S., Challender D. W. S., Khanyari M., Kupier T., Li Y., Olmedo A., Oyanedel R., Pienkowski T., \& Milner-Gulland E. J. Managing wildlife trade for sustainable development outcomes after COVID-19. SocArXiv, 2020. https://doi.org/10.31235/osf.io/2p3xt

14. Buckley R. Conservation implications of COVID19: Effects via tourism and extractive industries. Biological Conservation. 2020, 247, p. 108640. https://doi.org/10.1016/j. biocon.2020.108640

15. Budiman I. Enabling Community Participation for Social Innovation in the Energy Sector. Indonesian Journal of Energy. 2018. Available from: https://ije-pyc.org/index. php/IJE/article/view/23 (accessed: 15.09.2020)

16. Budiman I. The infection rate of the pandemic in dense cities. DSA Ireland, 2020, March 31. Available from: https://www.dsaireland.org/covid-19-resources/the-infectionrate-of-the-pandemic-in-dense-cities/ (accessed: 15.09.2020)

17. Budiman I., Bastoni Sari E. NN., Hadi E. E., Asmaliyah, Siahaan, H., Januar R., \& Hapsari R. D. Progress of paludiculture projects in supporting peatland ecosystem restoration in Indonesia. Global Ecology and Conservation, 2020, e01084. https://doi.org/10.1016/j.gecco.2020.e01084

18. Budiman I., \& Smits M. How Do Configuration Shifts in Fragmented Energy Governance Affect Policy Output? A Case Study of Changing Biogas Regimes in Indonesia. Sustainability. 2020, 12 (4), p. 1358. https://doi.org/10.3390/ su12041358

19. Budiman I., Takama T., Pratiwi L., \& Soeprastowo E. Role of microfinance to support agricultural climate change adaptations in Indonesia. Future of Food: Journal on Food, Agriculture and Society. 2016, 4 (3), pp. 55-68.

20. Carlson C. J. From PREDICT to prevention, one pandemic later. The Lancet Microbe. 2020, 1 (1), pp. e6-e7. https://doi.org/10.1016/S2666-5247(20)30002-1

21. Carrington D. Pandemics result from destruction of nature, say UN and WHO. The Guardian. 2020, June 17. Available from: https://www.theguardian.com/world/2020/ jun/17/pandemics-destruction-nature-un-who-legislationtrade-green-recovery (accessed: 15.09.2020)

22. CDC (Centers for Disease Control and Prevention). CDC Novel H1N1 Flu | The 2009 H1N1 Pandemic: Summary Highlights, April 2009-April 2010. 2010. Available from: https://www.cdc.gov/h1n1flu/cdcresponse.htm (accessed: 15.09.2020)

23. CDC, (Centers for Disease Control and Prevention). 1957-1958 Pandemic (H2N2 virus)| Pandemic Influenza (Flu) |CDC, 2019, January 22. Available from: https://www. cdc.gov/flu/pandemic-resources/1957-1958-pandemic.html (accessed: 15.09.2020)

24. Charlebois S. Coronavirus panic-buying: Industry implications. New Food Magazine, 2020. Available from: https:// www.newfoodmagazine.com/article/107095/coronaviruspanic-buying-industry-implications/ (accessed: 15.09.2020)

25. Daszak P., Cunningham A. A., \& Hyatt A. D. Emerging Infectious Diseases of Wildlife - Threats to Biodiversity and Human Health. Science. 2000, 287 (5452), pp. 443-449. https://doi.org/10.1126/science.287.5452.443

26. Drury R. Hungry for success: Urban consumer demand for wild animal products in Vietnam. Conservation and Society. 2011, 9 (3), pp. 247-257.

27. Eco-Business. Coronavirus has cut CO2 from Eu- 
rope's electricity system by 39 per cent. Eco-Business, 2020. Available from: http://www.eco-business.com/opinion/ coronavirus-has-cut-co2-from-europes-electricity-system-by39-per-cent/ (accessed: 15.09.2020)

28. Eskew E. A., \& Carlson C. J. Overselling wildlife trade bans will not bolster conservation or pandemic preparedness. The Lancet Planetary Health. 2020, 0 (0). https://doi. org/10.1016/S2542-5196(20)30123-6

29. Evans K. L., Ewen J. G., Guillera-Arroita G., Johnson J. A., Penteriani V., Ryan S. J., Sollmann R., \& Gordon I. J. Conservation in the maelstrom of Covid-19 - a call to action to solve the challenges, exploit opportunities and prepare for the next pandemic. Animal Conservation. 2020, 23 (3), pp. 235-238. https://doi.org/10.1111/acv.12601

30. Fajar J. Setelah 28 Tahun, Kualitas Udara di Jakarta Membaik: Mongabay.co.id., 2020. Available from: https:// www.mongabay.co.id/2020/04/06/setelah-28-tahun-kualitasudara-di-jakarta-membaik/ (accessed: 15.09.2020)

31. Faustini A., Rapp R., \& Forastiere F. Nitrogen dioxide and mortality: Review and meta-analysis of long-term studies. European Respiratory Journal. 2014, 44 (3), pp. 744-753.

32. Fawzi N. I., Qurani I. Z., \& Rahmasary A. N. Covid-19: A Zoonosis Related to Deforestation and Foodborne Disease. 2020, 4.

33. GCA. Welcome to Carbon Atlas. Global Carbon Atlas, 2018. Available from: http://www.globalcarbonatlas.org/en/ content/welcome-carbon-atlas (accessed: 15.09.2020)

34. Geography UI. (2020). PEMODELAN SPASIAL PERSEBARAN NO2. Available from: https://sicovid19-geography-ui. hub.arcgis.com/ (accessed: 15.09.2020)

35. Glenna L. The value of public agricultural and food knowledge during pandemics. Agriculture and Human Values. 2020, 1.

36. GWC. (2020). I CHOOSE TO END EXTINCTION. \#ExtinctionEndsHere. Available from: https://extinctionendshere. org/ (accessed: 15.09.2020)

37. Hays J. N. Epidemics and pandemics: Their impacts on human history. Abc-clio, 2005.

38. Henriques M. Will Covid-19 have a lasting impact on the environment. BBC News, 2020.

39. Ismail C. J., Takama T., Budiman I., \& Knight M. Comparative Study on Agriculture and Forestry Climate Change Adaptation Projects in Mongolia, the Philippines, and Timor Leste. In P. Castro, A. M. Azul, W. Leal Filho, \& U. M. Azeiteiro (Eds.). Climate Change-Resilient Agriculture and Agroforestry: Ecosystem Services and Sustainability. 2019, pp. 413-430. Springer International Publishing. https:// doi.org/10.1007/978-3-319-75004-0_24

40. Johnson C. K., Hitchens P. L., Pandit P. S., Rushmore J., Evans T. S., Young C. C., \& Doyle M. M. Global shifts in mammalian population trends reveal key predictors of virus spillover risk. Proceedings of the Royal Society B. 2020, 287 (1924), p. 20192736.

41. Jones K. E., Patel N. G., Levy M. A., Storeygard A., Balk D., Gittleman J. L., \& Daszak P. Global trends in emerging infectious diseases. Nature. 2008, 451 (7181), pp. 990-993.

42. Kahler J. S., \& Gore M. L. Beyond the cooking pot and pocket book: Factors influencing noncompliance with wildlife poaching rules. International Journal of Comparative and Applied Criminal Justice. 2012, 36 (2), pp. 103-120.

43. Kilbourne E. D. Influenza Pandemics of the 20th Century. Emerging Infectious Diseases. 2006, 12 (1), pp. 9-14. https://doi.org/10.3201/eid1201.051254

44. Klare M. Is the Covid-19 Pandemic Mother Nature's
Response to Human Transgression? Common Dreams, 2020. Available from: https://www.commondreams.org/ views/2020/04/02/covid-19-pandemic-mother-naturesresponse-human-transgression (accessed: 15.09.2020)

45. Last J. M., Harris S. S., Thuriaux M. C., \& Spasoff R. A. A dictionary of epidemiology. International Epidemiological Association, Inc., 2001.

46. Latinne A., Saputro S., Kalengkongan J., Kowel C. L., Gaghiwu L., Ransaleleh T. A., Nangoy M. J., Wahyuni I., Kusumaningrum T., \& Safari D. Characterizing and quantifying the wildlife trade network in Sulawesi, Indonesia. Global Ecology and Conservation. 2020, 21, p. e00887.

47. Liu X., Rohr J. R., \& Li Y. Climate, vegetation, introduced hosts and trade shape a global wildlife pandemic. Proceedings of the Royal Society B: Biological Sciences. 2013, 280 (1753), pp. 2012-2506. https://doi.org/10.1098/ rspb.2012.2506

48. Lubis M. I., Pusparini W., Prabowo S. A., Marthy W., Andayani N., \& Linkie M. Unraveling the complexity of human-tiger conflicts in the Leuser Ecosystem, Sumatra. Animal Conservation, 2020.

49. Memish Z. A., Mishra N., Olival K. J., Fagbo S. F., Kapoor V., Epstein J. H., AlHakeem R., Durosinloun A., Al Asmari M., \& Islam A. Middle East respiratory syndrome coronavirus in bats, Saudi Arabia. Emerging Infectious Diseases. 2013, 19 (11), p. 1819.

50. Morse S. S., Mazet J. A., Woolhouse M., Parrish C. R., Carroll D., Karesh W. B., Zambrana-Torrelio C., Lipkin W. I., $\&$ Daszak P. Prediction and prevention of the next pandemic zoonosis. The Lancet. 2012, 380 (9857), pp. 1956-1965. https://doi.org/10.1016/S0140-6736(12)61684-5

51. Muhammad S., Long X., \& Salman M. COVID-19 pandemic and environmental pollution: A blessing in disguise? Science of the Total Environment. 2020, p. 138820.

52. Nasralla S. Coronavirus could trigger biggest fall in carbon emissions since World War Two-Environment-The Jakarta Post, 2020. Available from: https://www.thejakartapost.com/life/2020/04/03/coronavirus-could-trigger-biggestfall-in-carbon-emissions-since-world-war-two.html (accessed: 15.09.2020)

53. Neupane D. How conservation will be impacted in the COVID-19 pandemic. Wildlife Biology. 2020, 2020 (2). https://doi.org/10.2981/wlb.00727

54. Newsome D. The collapse of tourism and its impact on wildlife tourism destinations. Journal of Tourism Futures. 2020.

55. Nijman V. An overview of international wildlife trade from Southeast Asia. Biodiversity and Conservation. 2010, 19 (4), pp. 1101-1114.

56. Null S. COVID-19 Could Affect Cities for Years. Here Are 4 Ways They're Coping Now. WRI Indonesia, 2020. Available from: https://wri-indonesia.org/en/blog/how-citiescoping-with-covid-19 (accessed: 00.00.0000)

57. OECD Statistics, 2011. Available from: https://stats. oecd.org/ (accessed: 15.09.2020)

58. Plowright R. K., Parrish C. R., McCallum H., Hudson P. J., Ko A. I., Graham A. L., \& Lloyd-Smith J. O. Pathways to zoonotic spillover. Nature Reviews Microbiology. 2017, 15 (8), pp. 502-510.

59. Purwanto A. Kualitas Udara Selama Masa Pandemi Covid-19. Kompas. Id., 2020, June 11. Available from: https:// kompas.id/baca/metro/2020/06/11/kualitas-udara-selamamasa-pandemi/ (accessed: 15.09.2020)

60. PwC. COVID-19: What it means for industrial manufacturing. PwC, 2020. https://www.pwc.com/us/en/library/ covid-19/coronavirus-impacts-industrial-manufacturing.html 
61. Robins N., Clover R., \& Singh C. A climate for recovery. The Colour of Stimulus Goes Green. London: HSBC Global Research. Updated Data Due to Contact to Author On, 2009, 16.

62. Rosalina P. Tantangan Normal Baru pada Perubahan Lingkungan. Kompas. Id., 2020, June 21. Available from: https://kompas.id/baca/riset/2020/06/21/tantangan-normal-baru-pada-perubahan-lingkungan/ (accessed: 15.09.2020)

63. Sharma S., Zhang M., Gao J., Zhang H., \& Kota S. H. Effect of restricted emissions during COVID-19 on air quality in India. Science of The Total Environment. 2020, 728, p. 138878.

64. Steinmetz R., Srirattanaporn S., Mor-Tip J., \& Seuaturien N. Can community outreach alleviate poaching pressure and recover wildlife in South-East Asian protected areas? Journal of Applied Ecology. 2014, 51 (6), pp. 1469-1478.

65. Susanto I. Tak Ada Anomali Iklim, Pandemi Covid-19 Perberat Pengendalian Kebakaran Hutan. Kompas. Id., 2020, June 4. Available from: https://kompas.id/baca/humaniora/ ilmu-pengetahuan-teknologi/2020/06/04/tak-ada-anomaliiklim-pandemi-covid-19-perberat-pengendalian-kebakaranhutan/ (accessed: 15.09.2020)

66. Symes W. S., Edwards D. P., Miettinen J., Rheindt F. E., \& Carrasco L. R. Combined impacts of deforestation and wildlife trade on tropical biodiversity are severely underestimated. Nature Communications. 2018, 9 (1), pp. 1-9.

67. Veríssimo D., Vieira S., Monteiro D., Hancock J., \& Nuno A. Audience research as a cornerstone of demand management interventions for illegal wildlife products: Demarketing sea turtle meat and eggs. Conservation Science and Practice. 2020, 2 (3), p. e164. https://doi.org/10.1111/ csp2.164

68. Volpato G., Fontefrancesco M. F., Gruppuso P., Zocchi D. M., \& Pieroni A. Baby pangolins on my plate: Possible lessons to learn from the COVID-19 pandemic. Springer, 2020.

69. Wang P., Chen K., Zhu S., Wang P., \& Zhang H. Severe air pollution events not avoided by reduced anthropogenic activities during COVID-19 outbreak. Resources, Conservation and Recycling. 2020, 158, p. 104814.

70. Watts J. Brazil: Coronavirus fears weaken Amazon protection ahead of fire season | Environment. The Guardian. 2020. Available from: https://www.theguardian.com/environ- ment/2020/apr/03/brazil-amazon-protection-coronavirusfire-season (accessed: 15.09.2020)

71. WeBank. WeBank 微众银行. 2020. Available from: https://www.webank.com/\#/home (accessed: 15.09.2020)

72. White M. C., \& Lowen A. C. Implications of segment mismatch for influenza A virus evolution. The Journal of General Virology. 2018, 99 (1), pp. 3-16. https://doi. org/10.1099/jgv.0.000989

73. Whiting K. Coronavirus isn't an outlier, it's part of our interconnected viral age. World Economic Forum, 2020. Available from: https://www.weforum.org/agenda/2020/03/ coronavirus-global-epidemics-health-pandemic-covid-19/ (accessed: 15.09.2020)

74. WHO. Hazard analysis and critical control point generic models for some traditional foods. WHO, 2018. Available from: https://applications.emro.who.int/dsaf/ dsa1 100.pdf?ua $=1$ (accessed: 15.09 .2020$)$

75. WRI. Build Back Better: Perspectives on COVID-19 Response and Recovery. World Resources Institute, 2020, March 30. Available from: https://www.wri.org/events/2020/04/ build-back-better-perspectives-covid-19-response-recovery (accessed: 15.09.2020)

76. WWF. THE LOSS OF NATURE AND RISE OF PANDEMICS. WWF, 2020. Available from: https://d2ouvy59p0dg6k. cloudfront.net/downloads/the_loss_of_nature_and_rise_of_ pandemics_protecting_human_and_planetary_health.pdf (accessed: 15.09.2020)

77. Xiao Y., \& Torok M. E. Taking the right measures to control COVID-19. The Lancet, Infectious Diseases. 2020, 20, pp. 523-524. https://doi.org/10.1016/S14733099(20)30152-3

78. Yi C. W., Ching S. C., \& Yu J. C. The outbreak of COVID-19: An overview. 2020.

79. Zhang R., Zhang Y., Lin H., Feng X., Fu T.-M., \& Wang Y. NOx Emission Reduction and Recovery during COVID-19 in East China. Atmosphere. 2020, 11 (4), p. 433.

80. Zheng,Y.-Y., Ma Y.-T., Zhang J.-Y., \& Xie X. COVID-19 and the cardiovascular system. Nature Reviews Cardiology. 2020, 17 (5), pp. 259-260.

\section{Contact details:}

Ibnu Budiman - MSc, a PhD candidate at the Department of Sciences, University of Wageningen, Postbox 8130, 6700EW, Wageningen, The Netherlands

E-mail: ibnu.budiman@wur.nl 